\title{
Evidence for the presence of two distinct membrane ATPases in Spiroplasma citri
}

\author{
PhilipPe SimoneaU AND JACQUes LABARÈRE*
}

Laboratoire de Génétique Moléculaire, Université de Bordeaux II - INRA, CRA de Bordeaux, BP 81, F-33883

Villenave d'Ornon Cedex, France

(Received 5 July 1990; revised 3 September 1990; accepted 17 September 1990)

\begin{abstract}
Triton X-100 (TX-100) extraction of Spiroplasma citri plasma membrane solubilized two types of ATPase differing in their $\mathrm{pH}$ of maximum activity. The activity measured at $\mathrm{pH} 8.5$ was inhibited by vanadate and the activity measured at pH 6.5 was not. The vanadate-sensitive ATPase had a relatively basic isoelectric point (8.65) and therefore could be separated from the vanadate-insensitive ATPase using chromatofocusing. Elution of the TX-100 membrane extract in a pH gradient from 9 to 6 generated two peaks of ATPase activity: one in the acidic range, composed of an $F_{0} F_{1}$-type ATPase, and one in the basic range, corresponding to the vanadate-sensitive activity. Electrophoretic analysis of proteins from the latter peak revealed one major polypeptide of $37 \mathrm{kDa}$. This peptide was shown to correspond to spot $\mathrm{A} 37$ in a two-dimensional protein map of $S$. citri. Using the gene for the $k d p$-operon of Escherichia coli as a probe in heterologous hybridization, sequences were detected in the genomic DNA of $S$. citri, suggesting that a gene coding for an enzyme related to this P-type ATPase is present in the $S$. citri genome. We therefore postulate the presense of two distinct kinds of ATPase in S. citri: one of the F-type which is resistant to vanadate inhibition, and one, probably of the P-type, which is vanadate-sensitive.
\end{abstract}

\section{Introduction}

Almost all bacterial ion-motive ATPases discovered to date can be grouped in two major categories designated $P$ and $F$ (Pedersen \& Carafoli, 1987). The latter are defined as those of the $F_{0} F_{1}$ type and are localized in the bacterial inner membrane. All of these enzymes that have been studied extensively, are hetero-oligomeric. Ion-motive ATPases of the P class are defined as those which form a covalent phosphorylated intermediate as part of their reaction cycle (Pedersen \& Carafoli, 1987). Such ATPases, which are generally homo-oligomeric, are all inhibited by vanadate (Macara, 1980). All Mollicutes tested so far possess a membrane-bound ATPase activity (Razin, 1978) which is thought to play a central role in the cell volume regulation of these wallless prokaryotes (Linker \& Wilson, 1985a; Shirvan et al., 1987). Among them, mycoplasmas and acholeplasmas (Zilberstein et al., 1986; Rottem et al., 1987) all possess at least one membrane ATPase closely related to the eubacterial $\mathrm{F}_{0} \mathrm{~F}_{1}$ ATPases. In Mycoplasma gallisepti-

Abbreviations: TX-100, Triton X-100; NEPHGE, non-equilibrium pH gel electrophoresis. cum, the presence of a second membrane ATPase transporting $\mathrm{Na}^{+}$at alkaline $\mathrm{pHs}$ has been postulated (Shirvan et al., 1987), and a $\mathrm{Na}^{+}$-stimulated ATPase has also been described in Acholeplasma laidlawii (Lewis \& McElhaney, 1983). The fact that (i) vanadate inhibits the $M$. gallisepticum enzyme (Linker \& Wilson, 1985b), and (ii) the $\mathrm{Na}^{+}$-stimulated ATPase in A. laidlawiii forms a covalent phosphorylated intermediate (Walderhaug et al., 1985), suggests that these two ATPases might be of the $P$ type. In contrast, although a protein cross-reacting with the $\beta$ subunit of Escherichia coli $\mathrm{F}_{1}$-ATPase has been detected in $S$. citri and Spiroplasma sp. strain BNR1 (Rottem et al., 1987), very little is known about Spiroplasma ATPases. It was therefore of interest to determine if these organisms also possess both types of ATPase. To this end we have examined the effects of $\mathrm{pH}$, in the presence or absence of vanadate, on the activity of solubilized $S$. citri ATPases. The results demonstrate that $S$. citri possesses two ATPases which differ markedly in their $\mathrm{pH}$ dependence and inhibitor sensitivity. These two activities were separated by chromatofocusing, and characterized by one- and two-dimensional gel electrophoresis. Heterologous hybridizations with selected probes were carried out to confirm the hypothesis that $S$. citri cells contain two types of ATPase. 


\section{Methods}

Solubilization and partial purification of the membrane-bound ATPase activities. Membranes ( $3 \mathrm{mg}$ protein $\left.\mathrm{ml}^{-1}\right)$, isolated as previously described (Simoneau \& Labarère, 1988), were solubilized for 1 h at $40^{\circ} \mathrm{C}$ in solubilization buffer $[40 \mathrm{~mm}$-Tris $/ \mathrm{HCl} \mathrm{pH} \mathrm{7.5,} 1$ mM-dithiothreitol, $25 \%(\mathrm{v} / \mathrm{v})$ glycerol] supplemented with $1 \%(\mathrm{w} / \mathrm{v})$ Triton $\mathrm{X}-100$ (TX-100). Non-solubilized material was removed by centrifugation for $30 \mathrm{~min}$ at $4{ }^{\circ} \mathrm{C}$ in a Kontron TST 55.5 rotor at 31000 r.p.m. The supernatant was concentrated at $4{ }^{\circ} \mathrm{C}$ by passage through a Minicon B 15 cell (Amicon). This concentrate was then dialysed at $4{ }^{\circ} \mathrm{C}$ against solubilization buffer containing $0 \cdot 25 \% \mathrm{TX}-100$ until the assayable concentration of detergent in the sample was $2.5 \mathrm{mg} \mathrm{ml}^{-1}$. One-tenth volume of 0.25 M-ethanolamine/acetate $\mathrm{pH} 9.4$ was added to the sample just before loading onto a column $(0.5 \times 5.5 \mathrm{~cm})$ of PBE94 (Pharmacia) which had been pre-equilibrated to $\mathrm{pH} 9.4$ with $0.025 \mathrm{M}$-ethanolamine/acetate pH 9.4 containing $0.25 \% \mathrm{TX}-100$. Elution was at $4{ }^{\circ} \mathrm{C}$ at a rate of $3 \mathrm{ml} \mathrm{h}^{-1}$ with polybuffer 96 (diluted 1:10, Pharmacia) previously adjusted to $\mathrm{pH} 6$ with acetic acid. One volume of $2 \times$ solubilization buffer containing $0 \cdot 25 \%$ TX-100 was added to each collected fraction in order to minimize loss of ATPase activity during storage.

Assay of ATPase activity. ATPase activity was determined spectrophotometrically at $32{ }^{\circ} \mathrm{C}$ by inorganic phosphate release as described by Dulley (1975) and expressed as nmol phosphate (mg protein) ${ }^{-1}$ $\mathrm{min}^{-1}$. The reaction medium contained, in a final volume of $100 \mu \mathrm{l}$ : $5 \mathrm{mM}$-ATP, $50 \mathrm{mM}$-Tris/malate $\mathrm{pH} 6.5$ or $8.5,1.5 \mathrm{mMMgCl}_{2}, 1.2 \mathrm{mM}$ $\mathrm{NaCl}$ and either $10 \mu \mathrm{l}$ of solubilized membranes (approximately 15$20 \mu \mathrm{g}$ protein) or $40 \mu \mathrm{l}$ of chromatofocusing fractions.

Electrophoresis of active enzyme. The solubilized enzyme was analysed by non-denaturing PAGE with ultrathin isoelectrofocusing $7.5 \%(\mathrm{w} / \mathrm{v})$ acrylamide gels containing $0.1 \% \mathrm{TX}-100$. The location of ATPase was determined by staining the gels for activity according to Nimmo \& Nimmo (1982). Briefly, gels were first soaked in equilibration buffer $(50 \mathrm{mM}$-Tris/ $\mathrm{HCl}, \mathrm{pH} 8)$ for $30 \mathrm{~min}$ at $4{ }^{\circ} \mathrm{C}$, then in the same buffer containing $1.25 \mathrm{mM}-\mathrm{MgCl}_{2}, 5 \mathrm{~mm}-\mathrm{NaCl}, 5 \mathrm{mM}-\mathrm{ATP}$, $10 \mathrm{mM}-\mathrm{CaCl}_{2}$, and incubated at $32{ }^{\circ} \mathrm{C}$ for several hours until the precipitated calcium salt, formed upon release of inorganic phosphate, gave a clearly visible white band. The $\mathrm{pH}$ gradient generated during the electrophoresis was checked by comigrating pl-marker proteins (Mixture 9, Serva)

Electrophoresis in SDS-polyacrylamide gels. Isoelectric focusing (IEF) was performed according to O'Farrell (1975); for non-equilibrium $\mathrm{pH}$ gel electrophoresis (NEPHGE), TX-100 extracts were adjusted to $0.1 \%$ (w/v) SDS, 9.2 M-urea and 4\% (v/v) ampholines (pH 3.5-10; LKBPharmacia). One volume of $9 \cdot 2 \mathrm{M}$-urea, $2 \cdot 5 \%(\mathrm{v} / \mathrm{v})$ ampholines, $4 \%$ $(\mathrm{w} / \mathrm{v})$ Nonidet $\mathrm{P} 40,5 \%(\mathrm{v} / \mathrm{v}) \beta$-mercaptoethanol was added to the samples just before loading the gels. Electrophoresis was then performed at $400 \mathrm{~V}$ for $4 \mathrm{~h}$. SDS-PAGE in the second dimension was as described by Mouchès et al. (1979). For immunodetection, proteins were blotted onto nitrocellulose sheets using a semi-dry blotting system (Kyshe-Andersen, 1984).

Hybridization on nitrocellulose filters. DNA was cleaved with restriction enzymes, separated by electrophoresis on 0.8 agarose gels and transferred to nitrocellulose filters according to Southern (1975). Restriction fragments used as probes were purified from $1 \%(\mathrm{w} / \mathrm{v})$ lowmelting agarose (Seaplaque, FMC) gels, labelled with [ $\left.{ }^{32} \mathrm{P}\right] \mathrm{dCTP}$ by random priming (Feinberg \& Vogelstein, 1984) and hybridized to genomic blots as described by Rasmussen \& Christiansen (1987).

Analytical methods. Protein concentration was determined by the method of Bradford (1976) by including 0.1\% TX-100 in the standards. TX-100 was determined by the method of Garenwal (1973).

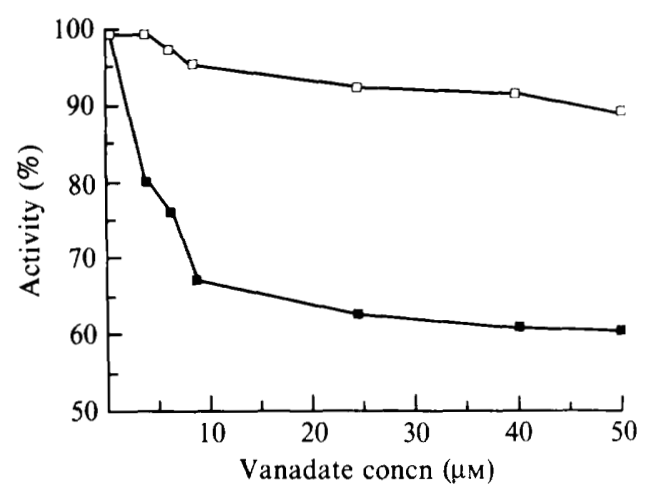

Fig. 1. Inhibition by vanadate of the TX-100-solubilized ATPase. The ATPase activity of a TX-100 extract, prepared as described in Methods, except that the reducing agent was omitted, was assayed at pH $6.5(\square)$ or $8.5(\square)$ in the presence of increasing amounts of vanadate. The activities are expressed as a percentage of the control without vanadate $\left(100 \%\right.$ activity corresponded to $50 \mathrm{nmol} P_{i}$ $\mathrm{mg}^{-1} \min ^{-1}$ ).

\section{Results}

Characterization of two ATPases with different $p H$ optima and sensitivities to vanadate in the membrane of $S$. citri

The ATPase activity of TX-100-solubilized membranes of $S$. citri was measured by determining the rate of release of $\mathrm{P}_{\mathrm{i}}$ from ATP at $\mathrm{pH} 4 \cdot 5-9 \cdot 5$. The activity exhibited a $\mathrm{pH}$ optimum in the neutral range, with a maximum at about 6.5, and another in the mild-alkaline range (at about 8.5 ). At $\mathrm{pH} 4.5$ or 9.5 , the hydrolytic activity was nearly completely abolished, decreasing to less than $15 \%$ of maximal; however, full activity could generally be recovered when the $\mathrm{pH}$ was brought back to either of the optima (data not shown). The stability of enzyme to high pHs was essential for chromatofocusing experiments, which involve exposure of the enzyme to $\mathrm{pH} 9 \cdot 4$. Based on these results, the presence of two ATPases in the TX100 extract of $S$. citri membranes was postulated.

One of the properties common to ion-motive ATPases involving a phosphorylated intermediate is inhibition by micromolar concentrations of orthovanadate (Hugentobler \& Solioz, 1983 ; O'Neal et al., 1979). In prokaryotes, this inhibitor also distinguishes those ATPases from the proton-translocating ones, which are unaffected by low concentrations of vanadate. Fig. 1 shows the vanadate inhibition curves for the TX-100soluble membrane ATPases at $\mathrm{pH} 6.5$ and 8.5. Under our assay conditions, vanadate inhibited the $S$. citri ATPase only at the alkaline $\mathrm{pH}$; half-maximal inhibition occurred at 5-7.5 $\mu \mathrm{M}$-orthovanadate. At inhibitor concentrations of $40 \mu \mathrm{M}$ or more, approximately $60 \%$ of the 

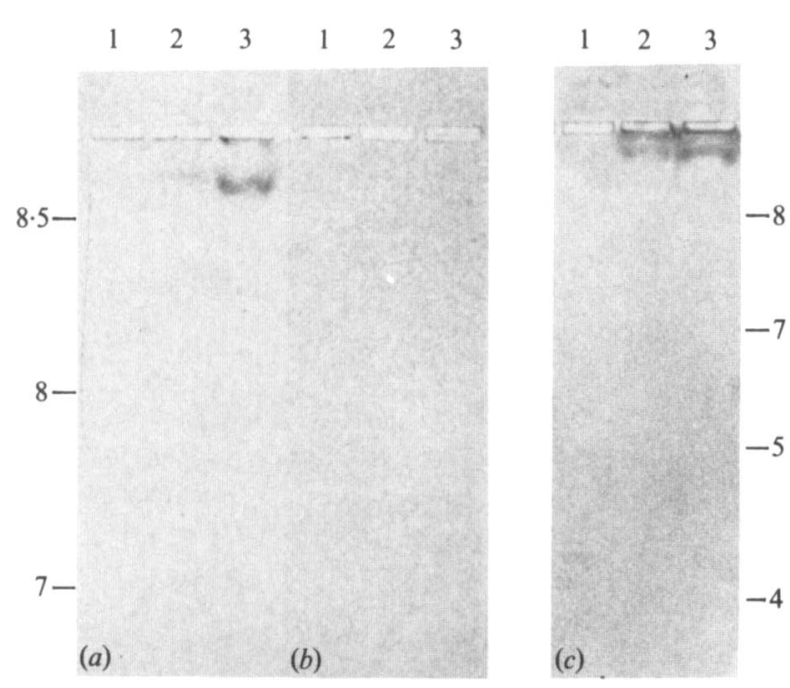

Fig. 2. Electrophoresis of TX-100-solubilized proteins on native polyacrylamide isoelectric focusing gels. TX-100-released proteins were separated on $7.5 \%$ polyacrylamide gels containing either ampholines 7-9 $(a, b)$ or ampholines 3-10 (c). Gels were stained for ATPase activity as described in Methods in the presence $(b)$ or absence $(a, c)$ of $50 \mu \mathrm{M}$-vanadate. Lanes 1 were loaded with $25 \mu \mathrm{g}$ of proteins previously heated at $100^{\circ} \mathrm{C}$ for $2 \mathrm{~min}$. Lanes 2 and 3 contained, respectively, 12.5 and $25 \mu \mathrm{g}$ of non-denatured protein. Numbers on the left and right refer to $\mathrm{pH}$ values determined as described in Methods.

activity remained vanadate insensitive. Therefore it appears that vanadate represents a tool to distinguish the two ATPases of $S$. citri: the activity measured at $\mathrm{pH} 6.5$ mainly represents the vanadate-insensitive ATPase, whereas that determined at $\mathrm{pH} 8.5$ in part corresponds to the vanadate-sensitive ATPase.

\section{Isoelectric point of the vanadate-sensitive ATPase}

The isoelectric point of the vanadate-sensitive ATPase was determined by running the TX-100 extract on nondenaturing polyacrylamide gels containing ampholines pH 7-9 (Fig. 2a,b) or pH 3-10 (Fig. 2c). A single band of ATPase was revealed; the isoelectric point of the enzyme was 8.65 (Fig. 2a). When vanadate was included in the incubation mixture, the detection signal was no longer observed (Fig. $2 b$ ). When electrophoresis was performed on a gel containing a broader $\mathrm{pH}$ gradient, again only one ATPase was stained (Fig. 2c). The lack of staining for the second ATPase was probably due to the conditions of $\mathrm{pH}$ and $\mathrm{Ca}^{2+}$ concentration (10 mM) we used rather than to electrophoresis conditions. Since the two ATPases of $S$. citri are both partially inhibited by $\mathrm{Ca}^{2+}$ (data not shown) and the level of $\mathrm{Ca}^{2+}$ required in this detection system is reduced at higher $\mathrm{pH}$ values (Nimmo \& Nimmo, 1982), the $\mathrm{pH}$ of the incubation mixture was

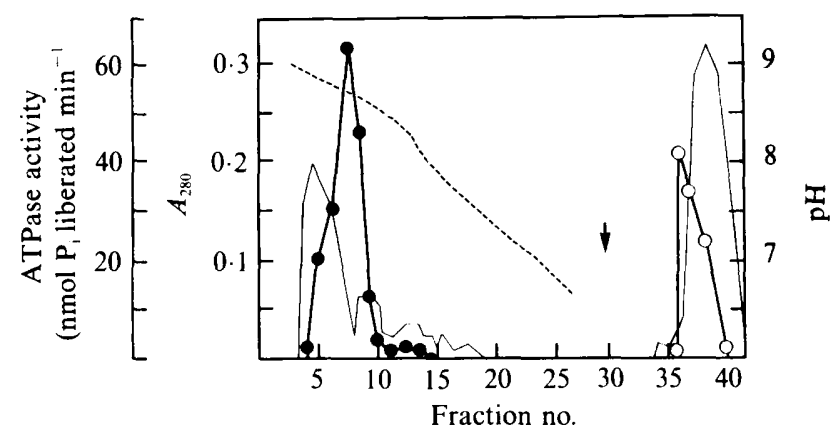

Fig. 3. Elution profile of ATPase activity from a chromatofocusing column. TX-100 extracts were applied to a PBE94 column equilibrated at $\mathrm{pH}$ 9.4. Elution was performed with polybuffer 96 at a flow rate of $3 \mathrm{ml} \mathrm{h}^{-1}$ and followed by measuring the absorbance at $280 \mathrm{~nm} \mathrm{(-)}$. Fractions of $0.5 \mathrm{ml}$ were collected and assayed for $\mathrm{pH}(--)$ and for vanadate-sensitive (O) and vanadate-insensitive $(O)$ ATPase activity. The arrow denotes the addition of $1 \mathrm{M}-\mathrm{NaCl}$.

raised to 8 . It is likely that residual vanadate-insensitive ATPase activity was too low in such a mild-alkaline environment to be visualized in a gel.

\section{Partial purification of the vanadate-sensitive ATPase}

As described above, preliminary studies on the vanadate-sensitive ATPase showed that this enzyme has a fairly alkaline isoelectric point. Since most membrane proteins of $S$. citri are moderately acid rather than basic (Simoneau \& Labarère, 1988), chromatofocusing seemed likely to be a powerful first purification step to enrich for the vanadate-sensitive ATPase from TX-100-solubilized membrane extracts. Fig. 3 shows the elution profile for chromatofocusing purification of $S$. citri vanadatesensitive ATPase using PBE94. Elution with polybuffer 96 over a pH gradient of 9-6 resulted in a single peak of vanadate-sensitive ATPase activity at $\mathrm{pH} \mathrm{8.62}$. Elution over the whole $\mathrm{pH}$ gradient did not result in elution of the second ATPase. However, this enzyme could subsequently be eluted with $1 \mathrm{M}-\mathrm{NaCl}$. This second peak of ATPase activity corresponds to the vanadate-insensitive ATPase. The specific activity of the enzyme in the fraction eluted at $\mathrm{pH} 8.62$ was $580 \mathrm{nmol} \mathrm{mg}^{-1} \mathrm{~min}^{-1}$ while that of the crude membranes was $40 \mathrm{nmol}$ $\mathrm{mg}^{-1} \mathrm{~min}^{-1}$. The combination of the TX-100 extraction and chromatofocusing step resulted in a 14.5-fold purification of the vanadate-sensitive ATPase.

Analysis of the vanadate-sensitive ATPase components by one-dimensional electrophoresis

The purification of the membrane vanadate-sensitive ATPase was monitored by PAGE in the presence of SDS 


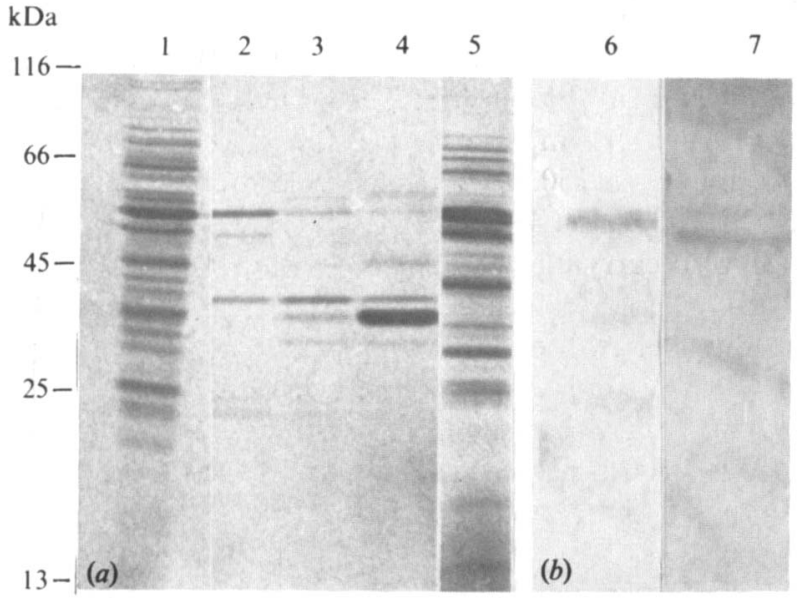

Fig. 4. Electrophoretic analysis of proteins from fractions eluted from the chromatofocusing column. Proteins were separated by SDS-PAGE and either stained by Coomassie blue $(a)$ or blotted to nitrocellulose filters $(b)$. Filters were used for immunodetection with anti-actin (lane 6) or anti- $\alpha \beta$ subunits from yeast $F_{1}$ ATPase (lane 7) sera. Gels were loaded with either $60 \mu \mathrm{g}$ of proteins from unfractionated TX-100 extracts (lane 1) or $50 \mu \mathrm{l}$ of the following chromatofocusing fractions fraction 6 (lane 2), 7 (lanes 3 and 6), 8 (lane 4) and 38 (lanes 5 and 7).

(Fig. 4a). Staining with Coomassie blue revealed one major polypeptide of about $37 \mathrm{kDa}$ in the fraction corresponding to the peak of vanadate-sensitive ATPase activity (Fig. 4a, lane 3). Since this was the major component that noticeably increased in parallel with the increase of vanadate-sensitive ATPase activity, we concluded that the $37 \mathrm{kDa}$ component was a subunit of this ATPase. There were minor contaminants with apparent molecular masses of about $55 \mathrm{kDa}$ and $35 \mathrm{kDa}$. However, these two polypeptides both became more prominent in fractions which did not correlate with the ATPase activity (Fig. 4a, lanes 1 and 4). Since the $55 \mathrm{kDa}$ contaminant did not separate from the $37 \mathrm{kDa}$ polypeptide even when further chromatography on Sephadex G200 column was performed (data not shown) it was of interest to further characterize this component. Two $55 \mathrm{kDa}$ proteins have been described in $S$. citri: the fibrillar protein (Townsend \& Archer, 1983) and a protein serologically related to actin (Simoneau \& Labarère, 1990). Blots of protein contained in the fraction eluted at $\mathrm{pH} 8.62$ were reacted either with antifibrillar or anti-actin sera. Cross-reactivity was obtained only in the latter case (Fig. $4 b$, lane 6) leading us to conclude that the $55 \mathrm{kDa}$ contaminant corresponded to the actin-related protein of $S$. citri. Electrophoretic analysis of proteins from the second peak of activity revealed about 20 separate polypeptides (Fig. $4 a$, lane 5), with subunit apparent molecular masses ranging from 10 to $80 \mathrm{kDa}$. When blots of proteins from this fraction were challenged with rabbit antiserum raised against yeast

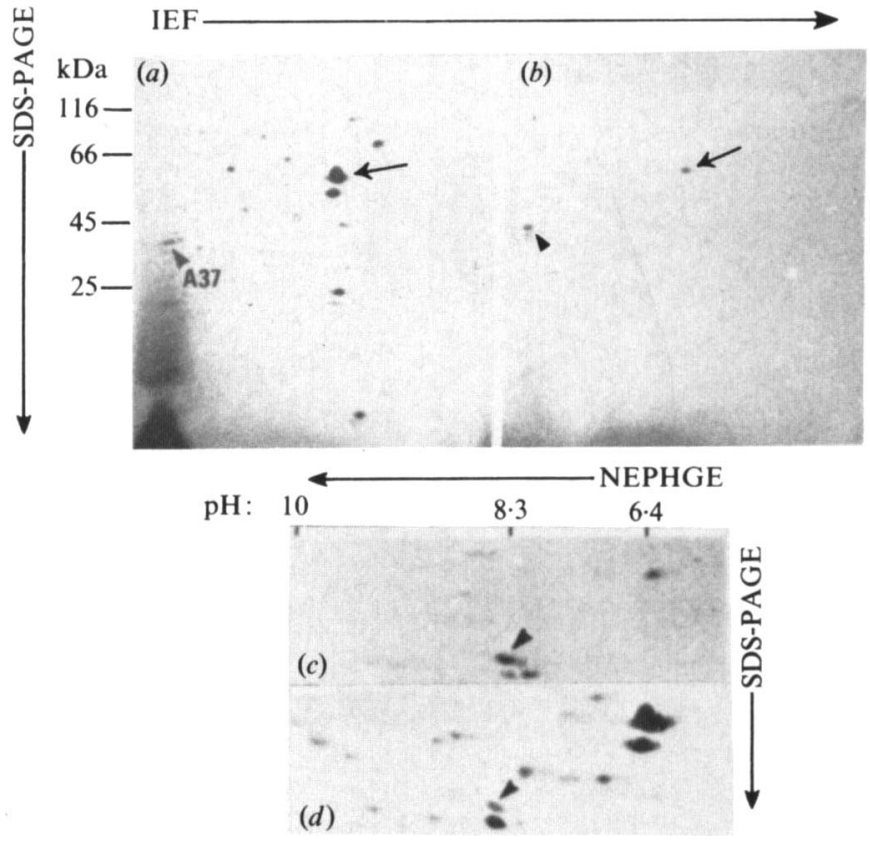

Fig. 5. Two-dimensional gel electrophoresis of the partially purified vanadate-sensitive ATPase. Proteins from the TX-100 extract $(a, d)$ or the chromatofocusing fraction which eluted at $\mathrm{pH} 8.62(b, c)$ were separated by IEF $(a, b)$ or NEPHGE $(c, d)$, followed by SDS-PAGE. Gels were stained with Coomassie blue. The arrows denote the $55 \mathrm{kDa}$ polypeptide (D55), and the arrowheads the $37 \mathrm{kDa}$ polypeptide (A37).

ATPase $\alpha \beta$ subunits, two cross-reacting polypeptides of 50 and $52 \mathrm{kDa}$ were detected (Fig. $4 b$, lane 7). This suggests that an ATPase serologically related to $F_{0} F_{1}$ ATPases was present in the fractions which eluted with high saline concentrations.

\section{Location by two-dimensional electophoresis of the vanadate-sensitive ATPase on the protein map of S. citri}

In order to identify the subunit(s) of the vanadatesensitive ATPase among $S$. citri proteins, two-dimensional gels of either TX-100 extracts or chromatofocusing fractions eluted at $\mathrm{pH} 8.62$ were compared (Fig. 5). When separated by IEF/SDS-PAGE, the latter was resolved into two major polypeptides (Fig. $5 b$ ). One polypeptide, with an apparent molecular mass of $55 \mathrm{kDa}$ and an isoelectric point of approximately 6.0 , corresponded to spot D55 in the TX-100 extract (Fig. 5a) (arrows). Previously published results have shown that this polypeptide is serologically related to actin (Simoneau \& Labarère, 1990). The other polypeptide, with an apparent molecular mass of $37 \mathrm{kDa}$ and a basic isoelectric point (higher than 7.5), corresponded to spot A37 in the TX-100 extract (arrowheads in Fig. 5). It has already been shown that this protein is located in membranes (Simoneau \& Labarère, 1988). A faint spot 


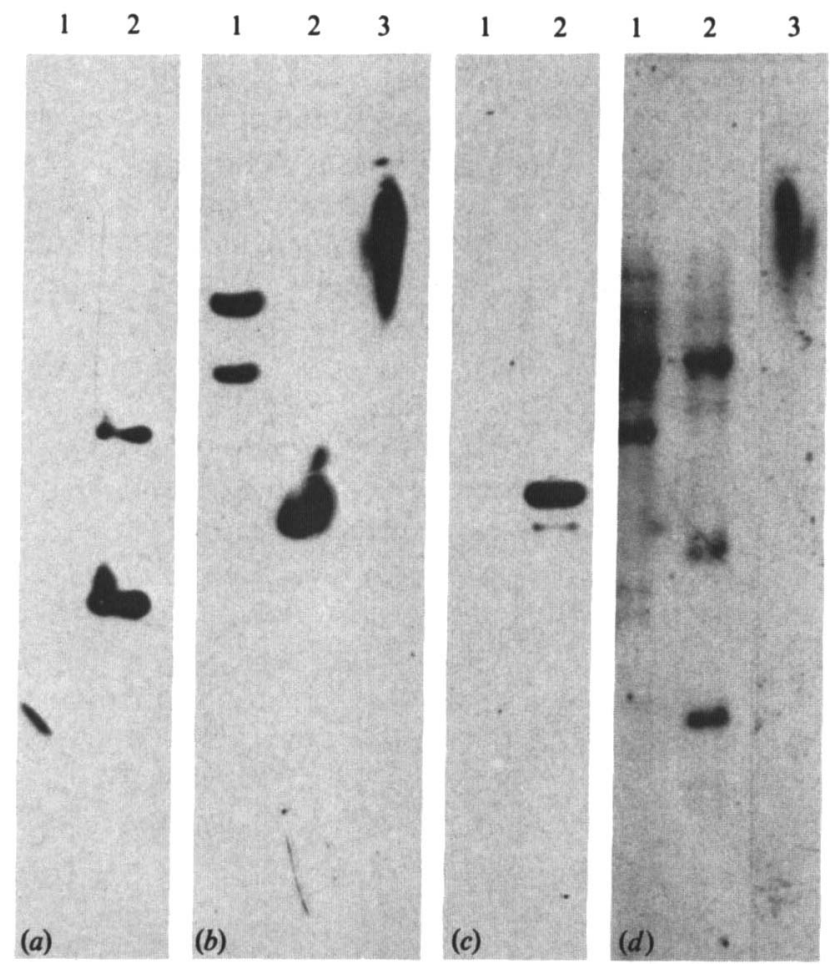

Fig. 6. Identification in S. citri genomic DNA of sequences related to the E. coli kdp operon and the Mycoplasma PG50 $\mathrm{H}^{+}$-ATPase. Plasmid or genomic DNA fragments were separated on $0.8 \%$ agarose gels, blotted onto nitrocellulose sheets and hybridized with probes for either the Mycoplasma PG50 $\mathrm{H}^{+}$-ATPase $\alpha$ subunit (pMYC405) $(a, b)$ or the E. coli $k d p$ operon (pWE1001) $(c, d)$. Gels were loaded as follows. $(a) 1$, HindIII-digested $\lambda$ phage; $2, X b a$ I-digested pMYC405. $(b, d) 1, E c o$ RIdigested $S$. citri DNA; 2, HindIII-digested $S$. citri DNA; 3, undigested $S$. citri DNA. (c) 1, HindIII-digested $\lambda$ phage; 2, EcoRI-digested pWE1001. Exposure times were $6 \mathrm{~h}(a, c), 12 \mathrm{~h}(b)$ and $24 \mathrm{~h}(d)$.

also appeared at approximately $35 \mathrm{kDa}$ just below A37, presumably corresponding to the minor contaminant previously detected by one-dimensional electrophoresis. Since poor resolution in the basic $\mathrm{pH}$ range is obtained upon isoelectrofocusing, two-dimensional gels with nonequilibrium $\mathrm{pH}$ gel electrophoresis in the first dimension were run (Fig. $5 c, d$ ). In this separation system, polypeptide A37 was resolved as a single spot with an isoelectric point of about $8 \cdot 3$. This $37 \mathrm{kDa}$ polypeptide in the vanadate-sensitive ATPase peak fraction showed an increase in staining intensity when compared to unfractionated TX-100 extract, whereas the $55 \mathrm{kDa}$ and $35 \mathrm{kDa}$ polypeptides decreased in parallel.

Screening for ATPases genes in the genome of S. citri by heterologous hybridization

The presence in the $S$. citri genome of sequences related to genes encoding two different types of ATPase from other micro-organisms was checked. Genomic blots of $S$. citri DNA cleaved with EcoRI or HindIII were probed with either a $3.5 \mathrm{~kb} X b a I$ fragment from plasmid pMYC405 carrying the gene for the $\alpha$ subunit of Mycoplasma PG50 $\mathrm{H}^{+}$-ATPase (Rasmussen \& Christiansen, 1987) or a $4.9 \mathrm{~kb} E c o R I$ fragment from plasmid pWE1001 carrying the $k d p$ operon of $E$. coli, which encodes a P-type ATPase (Hesse et al., 1984). After a maximum of $24 \mathrm{~h}$ exposure, hybridization signals were visible in all lanes where $S$. citri genomic DNA was analysed (Fig. $6 b, d$ ). When the inserts from pMYC405 and PWE1001, respectively, were used as probes, the following fragments were reproducibly labelled: EcoRI 13.3 and $8.3 \mathrm{~kb}$, HindIII $4.3 \mathrm{~kb}$; and EcoRI 9.2 and $6.4 \mathrm{~kb}$, HindIII $9.5,4$, and $2.6 \mathrm{~kb}$. To ensure that the hybridization signals, obtained in such low-stringency conditions, were due to the inserts and not to the vector part of recombinant plasmids, controls were carried out by hybridizing the $\mathrm{H}^{+}$-ATPase probe with $\mathrm{XbaI}$ digests of pMYC405 (Fig. 6a). No hybridization signal corresponding in size to the vector pSP65 was obtained. The two signals obtained were for the linearized form of pMYC405 generated by partial hydrolysis and for the cloned insert, respectively. Hybridization of the $k d p$ operon probe with EcoRI digests of PWE1001 (Fig. 6c) revealed two DNA fragments: one major band $(4.9 \mathrm{~kb})$ for the cloned insert and a weak signal $(4.3 \mathrm{~kb})$ for plasmid pBR322. In spite of this observation the hybridization signals obtained with $S$. citri DNA are likely to be due to the insert since probing $S$. citri genomic blots with pBR322 alone did not result in any hybridization signal, even under low-stringency conditions and after long times of exposure (data not shown).

\section{Discussion}

The data presented here support the notion that $S$. citri possesses at least two membrane-bound ATPases. In mycoplasmas, evidence has been presented that an ATPase, closely related to the $\mathrm{F}_{0} \mathrm{~F}_{1}$-ATPase of $E$. coli (Zilberstein et al., 1986; Rasmussen \& Christiansen, 1987) translocates protons across the membrane (Shirvan et al., 1987; Linker \& Wilson, 1985b). Our results strongly suggest that an ATPase of the F-type is also present in spiroplasmas. Indeed, two proteins that specifically interact with antiserum against the $\alpha$ and $\beta$ subunits of yeast $\mathrm{F}_{0} \mathrm{~F}_{1}-\mathrm{ATP}$ ase were detected in $S$. citri. Moreover, genomic DNA sequences of $S$. citri strongly hybridize with the Mycoplasma PG50 $\mathrm{H}^{+}$-ATPase operon, a sequence that shares regions of strong homology with the E. coli unc operon (Rasmussen \& Christiansen, 1987). Based on structural relatedness, we 
assume that this ATPase functions as an electrogenic $\mathrm{H}^{+}$ pump. In $S$. citri cells this enzyme constitutes only a part of the total ATPase activity. This conclusion rests on three lines of evidence: (i) the $\mathrm{pH}$ profile of the TX-100solubilized activities shows two distinct peaks of maximal activity; (ii) two types of chromatographically separable activities differ in their vanadate sensitivity; (iii) sequences related to the $E$. coli $k d p$-operon which encodes a P-type ATPase exist in the $S$. citri genome. This latter observation and the observed vanadate sensitivity give ground to the speculation that this second ATPase may be of the P-type. This would support the idea that transport ATPases of this class are present in many, probably most, bacteria (Walderhaug et al., 1989). The recent finding that a protein of Mycoplasma gallisepticum cross-reacts with anti-yeast plasma membrane ATPase serum (Shirvan et al., 1989), is also consistent with this assessment. However, the formation of a phosphorylated intermediate by the vanadatesensitive enzyme of $S$. citri remains to be examined. If this intermediate is formed, this ATPase would be strikingly different structurally from other ATPases belonging to this class: the previously described enzymes all consist of a single peptide $(\alpha)$ of $70-100 \mathrm{kDa}$. Exceptions are the eukaryotic $\mathrm{Na}^{+}-\mathrm{K}^{+}$ATPase, which contains an additional $\beta$ peptide of approximately $55 \mathrm{kDa}$, and the $\mathrm{Na}^{+}$-stimulated ATPase of Acholeplasma laidlawii, which contains five subunits of 68,55 , 35,27 and $16 \mathrm{kDa}$ (Lewis \& McElhaney, 1983). In the chromatographic fractions containing the partially purified vanadate-sensitive ATPase from $S$. citri, we found one major polypeptide of $37 \mathrm{kDa}$ and two other polypeptides of 55 and $35 \mathrm{kDa}$. The latter is probably a contaminant since it could easily be separated from the enzyme preparation upon gel filtration. Several results also suggest that the $55 \mathrm{kDa}$ component is not a subunit of the vanadate-sensitive ATPase: (i) the enrichment of this polypeptide during chromatofocusing does not completely correlate with the vanadate-sensitive activity; (ii) the location of this polypeptide, which crossreacts with anti-actin antibodies and corresponds to spot D55 in the protein map of $S$. citri, is not restricted to the membrane (Simoneau \& Labarère, 1988, 1990); and (iii) the isoelectric point of the native enzyme is nearly the same as that of the $37 \mathrm{kDa}$ peptide, which may indicate that this enzyme is homo-oligomeric. On the other hand, the observation that the $55 \mathrm{kDa}$ polypeptide does not separate from the $37 \mathrm{kDa}$ component during gel filtration or during chromatofocusing raises the possibility of interactions between these two peptides in the native enzyme. Interestingly, it has been shown recently that a $55 \mathrm{kDa}$ polypeptide of $S$. citri is reversibly phosphorylated in vivo (Rottem \& Platt, 1989). However, more work is required before it can be concluded that this polypeptide corresponds to spot D55 or to any other $55 \mathrm{kDa}$ protein spot (i.e. the fibrillar protein).

In view of the biological significance of ion-motive ATPases in the maintenance of constant internal $\mathrm{pH}$ and cell volume regulation, especially for Mollicutes, which lack a rigid cell wall, it would be interesting to determine the physiological function of the vanadate-sensitive ATPase of $S$. citri. Recent studies have shown that $M$. gallisepticum, may also possess two different ATPases (Shirvan et al., 1987, 1989). Speculation that the Spiroplasma vanadate-sensitive enzyme is involved in sodium extrusion, as has been suggested in $M$. gallisepticum, is premature. Clearly, further research is needed to assign a role to the vanadate-sensitive ATPase. The successful separation of the two solubilized ATPase activities by chromatofocusing, reported here, will prove helpful for such future studies. As mentioned above, the vanadate-sensitive ATPase of $S$. citri might be structurally somewhat different from other P-type ATPases. Nevertheless, our hybridization data suggest that at least part of this enzyme resembles the $E$. coli $k d p \mathrm{~K}^{+}$-ATPase, at the DNA level. This was unexpected if we consider the fact that in several Gram-positive bacteria no homologues of $k d p$ genes were detected (Walderhaug et al., 1989). However, phylogenic studies have shown that Mollicutes arose by degenerative evolution from Clostridium spp. (Woese, 1987), and to our knowledge to date no clostridia have been tested. Heterologous hybridizations might also prove a useful tool for cloning and sequencing the gene for vanadate-sensitive ATPase. The small size of the vanadate-sensitive ATPase catalytic subunit of $S$. citri, compared to that of corresponding prokaryotic ATPases, may be in line with the concept of 'economy in genetic information' in micro-organisms with a small genome (Morowitz, 1984). Therefore such sequence data are of interest particularly from an evolutionary point of view and will probably provide information concerning the minimal features required in the mechanism of energized transport. Taken together, the results obtained by both the biochemical approach and the hydridization experiments will facilitate further functional and molecular characterization of Spiroplasma membrane ATPases, the ultimate objective of such studies being to obtain insights into the proton- and ion-pumping mechanisms in spiroplasmas. Our finding that two types of ATPase are present in the membrane of $S$. citri should greatly facilitate the interpretation of future results.

\footnotetext{
We would like to thank Dr Ole F. Rasmussen (Technical University of Denmark) for providing us with plasmid pMYC405 and Dr Wolfgang Epstein (University of Chicago, USA) for generous gift of plasmid PWE1001. The gifts of antibodies against the F1 subunits of yeast ATPase by Dr Michael G. Douglas (University of Texas, USA) and against the Spiroplasma fibrillar protein by Dr David $L$. Williamson (University of New York, USA) were very much
} 
appreciated. We are indebted to Dr Martine Guérin (CNRS, Bordeaux, France) for helpful discussions and to Dr Geraldine Fleming (University of North Carolina, USA) for assistance in the preparation of this manuscript. This work was supported by the Conseil Scientifique de l'Université de Bordeaux II and the Institut National de la Recherche Agronomique.

\section{References}

BRADFORD, M. M. (1976). A rapid and sensitive method for the quantitation of microgram quantities of protein utilizing the principle of protein-dye binding. Analytical Biochemistry 72, 248254.

Dulley, J. R. (1975). Determination of inorganic phosphate in the presence of detergents or protein. Analytical Biochemistry 67, 91-96.

Feinberg, A. P. \& Vogelstein, B. (1984). A technique for radiolabeling DNA restriction fragments to high specific activity. Analytical Biochemistry 137, 266-267.

GARENWAL, H. S. (1973). A procedure for the estimation of microgram quantities of Triton X-100. Analytical Biochemistry 54, 319-324.

Hesse, J. E., Wieczorek, L., Altendorf, K., Reicin, A. S., Dorus, E. \& EPSTEIN, W. (1984). Sequence homology between two membrane transport ATPases, the Kdp-ATPase of Escherichia coli and the $\mathrm{Ca}^{2+}$-ATPase of sarcoplasmic reticulum. Proceedings of the National Academy of Sciences of the United States of America 81, 4746-4750.

Hugentobler, G. \& Solioz, M. (1983). Purification of a putative $\mathrm{K}^{+}$. ATPase from Streptococcus faecalis. Journal of Biological Chemistry 258, 7611-7617.

KYHSE-ANDERSEN, J. (1984). Electroblotting of multiple gels: a simple apparatus without buffer tank for rapid transfer of proteins from polyacrylamide to nitrocellulose. Journal of Biochemical and Biophysical Methods 10, 203-209.

Lewis, N. A. H. \& MCElhaney, R. N. (1983). Purification and characterization of the membrane $\left(\mathrm{Na}^{+} / \mathrm{Mg}^{++}\right)$-ATPase from Acholeplasma laidlawii B. Biochimica et Biophysica Acta 735, 113-122.

LINKER, C. \& WiLson, T. H. (1985a). Cell volume regulation in Mycoplasma gallisepticum. Journal of Bacteriology 163, 1243-1258.

LINKER, C. \& WILSON, T. H. (1985b). Characterization and solubilization of the membrane-bound ATPase of Mycoplasma gallisepticum. Journal of Bacteriology 163, 1262-1269.

MaCARA, I. G. (1980). Vanadium: an element in search of a role. Trends in Biochemical Sciences 5, 92-94.

Morowitz, H. J. (1984). The completeness of molecular biology. Israel Journal of Medical Sciences 20, 750-753.

Mouchès, C., Vignault, J. C., Tully, J. G., Whitcomb, R. F. \& Bové, J. M. (1979). Characterization of Spiroplasmas by one- and two-dimensional protein analysis on polyacrylamide slab gels. Current Microbiology 2, 69-74.
Nimmo, H. G. \& Nimmo, G. A. (1982). A general method for the localization of enzymes that produce phosphate, pyrophosphate, or $\mathrm{CO}_{2}$ after polyacrylamide gel electrophoresis. Analytical Biochemistry 121, 17-22.

O'FARRell, P. H. (1975). High resolution two-dimensional electrophoresis of proteins. Journal of Biological Chemistry 250, 4007-4021.

O'NeAl, S., RHoADS, D. B. \& RACKER, E. (1979). Vanadate inhibition of sarcoplasmic reticulum $\mathrm{Ca}^{2+}$-ATPase and other ATPases. Biochemical and Biophysical Research Communications 89, 845-850.

Pedersen, P. L. \& Carafoli, E. (1987). Ion motive ATPases. I. Ubiquity, properties, and significance to cell function. Trends in Biochemical Sciences 12, 146-150.

Rasmussen, O. F. \& Christiansen, C. (1987). Identification of the proton ATPase operon in Mycoplasma strain PG50 by heterologous hybridization. Israel Journal of Medical Sciences 23, 393-397.

Razin, S. (1978). The mycoplasmas. Microbiological Reviews 42, 414 470.

RotTem, S. \& Platt, M. W. (1989). Protein phosphorylation in spiroplasmas. Zentralblatt für Bakteriologie 20, 139-144.

Rottem, S., Shirvan, M. H., Barile, M. F. \& Zilberstein, D. (1987). Immunochemical evidence for an active $\left(\mathrm{F}_{1}-\mathrm{F}_{0}\right)-\mathrm{ATPase}$ in mycoplasmas. Israel Journal of Medical Sciences 23, 389-391.

ShiRvan, M. H., Schuldiner, S. \& RotTeM, S. (1987). Control of sodium fluxes in Mycoplasma gallisepticum. Israel Journal of Medical Sciences 23, 384-388.

ShIRVAN, M. H., Schuldiner, S. \& RotTem, S. (1989). Volume regulation in Mycoplasma gallisepticum: evidence that $\mathrm{Na}^{+}$is extruded via a primary $\mathrm{Na}^{+}$pump. Journal of Bacteriology 171, 44174424.

SimoneaU, P. \& LABARÈRE, J. (1988). Isolation of Spiroplasma citri membranes and characterization of membrane proteins by twodimensional gel electrophoresis. Current Microbiology 16, 229-235.

SimoneAu, P. \& Labarère, J. (1990). Immunochemical identification of an actin-like protein from Spiroplasma citri. Zentralblatt für Bakteriologie 20, 927-931.

SOUTHERN, E. (1975). Detection of specific sequences among DNA fragments separated by gel electrophoresis. Journal of Molecular Biology 98, 503-517.

TOWNSEND, R. \& ARCher, D. B. (1983). A fibril protein antigen specific to Spiroplasma. Journal of General Microbiology 129, 199206.

Walderhaug, M. O., Post, R. L., Saccomani, G., Leonard, R. T., \& BRISKIN, D. P. (1985). Structural relatedness of three ion-transport adenosine triphosphatases around their active sites of phosphorylation. Journal of Biological Chemistry 260, 3852-3859.

Walderhaug, M. O., Litwack, E. D. \& EpTStein, W. (1989). Wide distribution of homologs of $E$. coli $K d p \mathrm{~K}^{+}$-ATPase among Gramnegative bacteria. Journal of Bacteriology 171, 1192-1195.

WoEsE, C. R. (1987). Bacterial evolution. Microbiological Reviews 51, 221-271.

Zilberstein, D., ShiRvan, M. H., Barile, M. F. \& Rottem, S. (1986). The $\beta$-subunit of the $\mathrm{F}_{1} \mathrm{~F}_{0}$-ATPase is conserved in mycoplasmas Journal of Biological Chemistry 261, 7109-7111. 